\title{
Hubungan Status Gizi dengan Siklus Menstruasi pada Mahasiswi Fakultas Kedokteran Universitas Andalas
}

\author{
Yana Aurora Prathita ${ }^{1}$, Syahredi ${ }^{2}$, Nur Indrawati Lipoeto ${ }^{3}$
}

\begin{abstract}
Abstrak
Siklus menstruasi merupakan pertanda klinis fungsi reproduksi wanita. Ada beberapa faktor yang mempengaruhi siklus menstruasi, seperti lemak tubuh. Banyaknya lemak dalam tubuh dapat menyebabkan memanjangnya siklus menstruasi. Tujuan penelitian ini adalah untuk mengetahui hubungan persentase lemak tubuh dan Indeks Massa Tubuh (IMT) terhadap keteraturan siklus menstruasi pada wanita. Penelitian ini menggunakan desain penelitian cross sectional study. Populasi adalah seluruh mahasiswi Fakultas Kedokteran Universitas Andalas. Sampel diambil sebanyak 79 responden secara simple random sampling. Pengambilan data dilakukan dengan menggunakan metode wawancara dengan kuesioner dan pengukuran antropometri (BB, TB, persentase lemak tubuh dengan menggunakan alat skinfold caliper). Data yang didapatkan dianalisis dengan uji chi-square. Hasil penelitian menunjukkan sebagian besar responden memiliki (IMT) dan persentase lemak tubuh normal, yaitu $72,15 \%$ dengan IMT $<23,00 \mathrm{~kg} / \mathrm{m} 2$ dan $64,6 \%$ persentase lemak tubuh $<22,1 \%$. Tidak ada hubungan yang berarti antara siklus menstruasi dengan IMT dan persentase lemak tubuh, $p=0,77$ untuk hubungan siklus menstruasi dengan IMT, dan $p=0,31$ untuk hubungan siklus menstruasi dengan persentase lemak tubuh. Simpulan studi ini adalah tidak terdapat hubungan berarti antara persentase lemak tubuh dan IMT dengan keteraturan siklus menstruasi.
\end{abstract}

Kata kunci: IMT,persentase lemak tubuh, siklus menstruasi

\begin{abstract}
Menstrual cycle is a functional women health reproduction. There are some factors affect menstrual cycle, such as body fat. Amount of body fat could make menstrual cycle longer. The objective of this study was to determine association of body fat percentage and Body Mass Index (BMI) on menstrual cycle. This was a cross sectional study, population of this study are all of the women college student. There are 79 respondents chosen based simple random sampling under inclusion criteria. Data was taken by interviewing sample with questioner and anthropometry assessment (weight, height, body fat percentage using skinfold caliper). Statistical analysis by chi-square. The results showed that most of respondent have normal Body Mass Index (BMI) and body fat percentage, 72.15\% respondents having $\mathrm{BMl}<23.00 \mathrm{~kg} / \mathrm{m} 2$ and $64.6 \%$ having body fat percentage $<22.1 \%$. Bivariate analysis shown $p=0.77$ for association BMI with menstrual cycle and $p=0.31$ for association menstrual cycle with body fat percentage. The result is no association BMI and body fat percentage on menstrual cycle. It can be concluded that there is no association between body fat percentage and BMI on menstrual cycle.
\end{abstract}

Keywords: BMI, body fat percentage, menstrual cycle

Affiliasi penulis: Prodi Profesi Dokter FK Unand (Fakultas Kedokteran Universitas Andalas Padang) 2. Bagian Kebidanan dan Penyakit Kandungan FK Unand/RSUP Dr. M. Djamil Padang, 3. Bagian IImu Gizi FK Unand

Korespondensi: Yana Aurora Prathita, Email:

yana_prathita@ymail.com, Telp: 087895528897

\section{PENDAHULUAN}

Menstruasi merupakan proses kompleks yang melibatkan beberapa hormon, organ seksual dan sisterm saraf. Hormon memiliki pengaruh penting dalam menstruasi, jika hormon tidak seimbang maka 
siklus akan terganggu. Siklus menstruasi merupakan pertanda klinis fungsi reproduksi wanita. ${ }^{1}$ Panjang siklus menstruasi diketahui sebagai prediktor kesehatan seperti kanker payudara dan faktor risiko kardiovaskular. ${ }^{2}$ Siklus menstruasi didefinisikan siklus pendek jika $\leq 25$ hari, normal 26-34 hari, atau panjang $\geq 35$ hari. $^{3}$ Siklus menstruasi yang tidak normal juga dikaitkan dengan penurunan fertilitas. ${ }^{4}$ Jarak siklus menstruasi berbeda pada setiap wanita, umumnya berkisar 15-45 hari rata-rata 28 hari dan lamanya berkisar 2-8 hari rata-rata 4-6 hari dengan darah yang dikeluarkan berkisar $60-80 \mathrm{ml}$ per siklus. ${ }^{5}$ Berat badan sebagai representasi massa lemak tubuh memiliki pengaruh terhadap keseimbangan hormon dan menstruasi. Berat badan berlebih dan obesitas merupakan kondisi abnormal ditandai dengan penumpukan lemak berlebihan melebihi batas kebutuhan skeletal dan fisik yang dapat mengganggu kesehatan. ${ }^{6}$ Dalam penelitian yang dilakukan oleh Dahliansyah tahun 2003 menyatakan bahwa ada hubungan antara lemak tubuh dengan siklus menstruasi. Jika seorang wanita memiliki berat badan di bawah rata-rata maka hormon dalam tubuh akan berhenti bekerja dan siklus menstruasi pun akan berhenti. Wanita obesitas memiliki peluang dua kali lipat lebih besar untuk mengalami siklus ireguler dibandingkan dengan wanita yang memiliki berat badan normal. $^{7}$

Hiperkolesterolemia identik dengan obesitas ditandai dengan kadar trigliserida dan LDL (Low Density Lipoprotein) dalam darah yang tinggi. Kolesterol adalah salah satu bahan pembentuk hormon steroid. Ovarium memproduksi steroid melalui sel teka yang menghasilkan androgen dan merespon LH (Luetinizing Hormon) dengan meningkatkan jumlah reseptor LDL untuk memasukkan kolesterol ke dalam sel, selain itu LH juga berfungsi menstimulasi aktivitas protein khusus yaitu P450scc yang akan meningkatkan produksi androgen yang nantinya akan di metabolisme oleh aromatase menjadi estrogen. ${ }^{8}$

Data penduduk berumur di atas 20 tahun di Amerika Serikat tahun 2009-2010 menunjukkan sebanyak $27,9 \%$ perempuan mengalami berat badan berlebih dan $35,8 \%$ mengalami obesitas. ${ }^{9}$ Faktanya, dilndonesia tercatat pada tahun 2003 sebanyak 17,4\% wanita mengalami berat badan berlebih dan 4,5\% mengalami obesitas. ${ }^{10}$

Berat badan merupakan indikator kesehatan seseorang, tetapi pembentuk tubuh dan komposisinya sangat bervariasi, sehingga berat badan tidak ideal digunakan sebagai indikasi simpanan lemak seseorang. Untuk itu diperlukan pengukuran lain yang lebih baik secara kuantitas seperti Indeks Massa Tubuh (IMT) / Body Mass Index (BMI), lingkar pinggang, rasio pinggang/pinggul, dan lain lain. Pengukuran menggunakan IMT saja bukan merupakan ukuran yang sempurna karena tidak dapat menyajikan indikasi akurat lemak tubuh sehingga diperlukan pengukuran lingkar pinggang dan rasio pinggang/pinggul (RLPP). ${ }^{11}$ Selain pengukuran IMT, metode yang sering digunakan untuk mengukur lemak badan total (dinyatakan sebagai persentase lemak tubuh) menggunakan skinfold caliper. ${ }^{12}$

Siklus menstruasi juga dipengaruhi oleh usia, status gizi, keadaan emosi dan massa lemak tubuh. Harlow dan Matanoski pada tahun 1991 juga menemukan bahwa berat badan berlebih memiliki hubungan dengan kemungkinan terjadinya siklus menstruasi lebih panjang pada kelompok mahasiswi. ${ }^{13}$

Pada penelitian yang dilakukan di sebuah SMU di Semarang didapatkan sejumlah kecil dari remaja yang diteliti, persentase lemak tubuh merupakan faktor risiko ringan bagi terjadinya ketidakteraturan siklus menstruasi, dan remaja putri dengan lingkar pinggang kategori obesitas lebih tinggi yang mengalami siklus menstruasi tidak teratur. ${ }^{4}$

\section{METODE}

Jenis penelitian yang dilakukan adalah analitik observasional dengan pendekatan cross-sectional study. Penelitian dilakukan pada mahasiswi Fakultas Kedokteran Universitas Andalas dilaksanakan dari Maret 2012-Februari 2013. Sampel pada penelitian ini berjumlah 79 orang. Teknik pengambilan sampel yang digunakan adalah Propotional Random Sampling pengambilan sampel secara proporsi dilakukan dengan cara mengambil subyek dari setiap angkatan ditentukan seimbang atau sebanding dengan banyaknya subyek dalam masing-masing angkatan. 
Variabel bebas pada penelitian ini adalah Status gizi yaitu IMT dan persentase lemak tubuh. Sedangkan, variabel terikat adalah siklus menstruasi. Penelitian ini, instrumen yang digunakan adalah microtoise, timbangan berat badan, dan skinfold calliper untuk mengukur antopometri serta kuesioner untuk menanyakan siklus menstruasi. Data yang diperoleh diolah dengan komputer berupa uji analisis chi-square dengan tingkat pemaknaan $p<0,05$.

\section{HASIL}

Data yang diperoleh dari 79 sampel yang merupakan mahasiswi Fakultas Kedokteran Universitas Andalas didapatkan hasil sebagai berikut.

Tabel 1. Data tinggi badan, berat badan, dan umur responden penelitian

\begin{tabular}{llll}
\hline Parameter & Minimum & Maksimum & Mean \\
\hline $\begin{array}{l}\text { Berat badan } \\
(\mathrm{kg})\end{array}$ & 38 & 76 & $52,04 \pm 8,94$ \\
$\begin{array}{l}\text { Tinggi badan } \\
(\mathrm{cm})\end{array}$ & 141 & 171 & $155,27 \pm 5,6$ \\
Umur (tahun) & 18 & 22 & $19,54 \pm 1,1$ \\
\hline
\end{tabular}

Berdasarkan Tabel 1 didapatkan bahwa berat badan terbesar responden adalah $76 \mathrm{~kg}$ dengan ratarata $52,04 \pm 8,94 \mathrm{~kg}$. Nilai maksimum tinggi badan

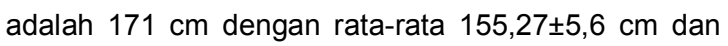
umur tertinggi pada umur 22 tahun dengan rata-rata $19,54 \pm 1,1$ tahun.

Table 2. Indeks massa tubuh responden penelitian

\begin{tabular}{ccc}
\hline IMT $\left(\mathbf{k g} / \mathbf{m}^{\mathbf{2}}\right)$ & $\mathbf{f}$ & Persentase (\%) \\
\hline Non Overweight & 57 & 72,15 \\
Overweight & 22 & 27,85 \\
Total & 79 & 100 \\
\hline
\end{tabular}

Tabel 2 menunjukkan populasi memiliki IMT overweight sebanyak $27,85 \%$.

tabel 3. Tebal lemak tubuh responden penelitian

\begin{tabular}{|c|c|c|}
\hline Total Lemak Tubuh & $f$ & Persentase (\%) \\
\hline Normal & 51 & 64,6 \\
\hline Overweight & 28 & 35,4 \\
\hline Total & 79 & 100 \\
\hline
\end{tabular}

Berdasarkan Tabel 3 terlihat sebagian besar populasi memiliki persentase lemak tubuh dalam kategori non overweight yaitu berjumlah 51 sampel $(64,6 \%)$ dan overweight 28 sampel $(35,4 \%)$. Nilai rata rata persentase lemak adalah $19,33 \pm 4,94$.

Tabel 4. Siklus menstruasi responden penelitian

\begin{tabular}{|c|c|c|}
\hline Kategori & $\bar{f}$ & Persentase (\%) \\
\hline Teratur & 68 & 86,07 \\
\hline Tidak Teratur & 11 & 13,9 \\
\hline Jumlah & 79 & 100 \\
\hline
\end{tabular}

Berdasarkan Tabel 4 terlihat sebagian besar responden sebanyak 68 orang memiliki siklus menstruasi yang teratur yaitu dengan rentang 21-35 hari dalam 3 bulan terakhir. Hanya 11 orang (13,9\%) yang mengalami siklus menstruasi tidak teratur. Siklus menstruasi terpanjang adalah 45 hari dan terpendek 18 hari dengan rata-rata siklus menstruasi $30,63 \pm 4,64$ hari.

Tabel 5. Hubungan siklus menstruasi dengan IMT

\begin{tabular}{|c|c|c|c|c|c|c|c|}
\hline \multirow{3}{*}{ Kategori IMT } & \multicolumn{6}{|c|}{ Siklus Menstruasi } & \multirow{3}{*}{$\mathbf{P}$} \\
\hline & \multicolumn{2}{|c|}{ Teratur } & \multicolumn{2}{|c|}{$\begin{array}{c}\text { Tidak } \\
\text { Teratur }\end{array}$} & \multicolumn{2}{|c|}{ Total } & \\
\hline & f & $\%$ & f & $\%$ & f & $\%$ & \\
\hline Overweight & 20 & 25,3 & 2 & 2,5 & 22 & 100 & \\
\hline $\begin{array}{c}\text { Non- } \\
\text { overweight }\end{array}$ & 48 & 60,7 & 9 & 11,3 & 57 & 100 & 0,77 \\
\hline Total & 68 & 85,9 & 11 & 13,8 & 79 & 100 & \\
\hline
\end{tabular}

Pada Tabel 5, responden overweight lebih banyak yang mengalami siklus menstruasi teratur sebanyak 20 orang $(25,3 \%)$ dibandingkan dengan yang overweight dengan ketidakteraturan mestruasi dengan jumlah 2 orang (2,5\%). Dari hasil uji statistik didapatkan $p=0,77$, hal ini menunjukkan bahwa tidak terdapat hubungan bermakna antara IMT dengan keteraturan siklus menstruasi.

Berdasarkan Tabel 6 didapatkan responden overweight yang mengalami ketidakteraturan menstruasi hanya kurang dari lima responden sedangkan jumlah responden non overweight yang mengalami ketidakteraturan menstruasi lebih banyak dibandingkan responden overweight. Dari hasil uji 
statistik didapatkan $\mathrm{p}=0,31$, hal ini menunjukkan bahwa tidak ada hubungan persentase lemak tubuh dengan siklus menstruasi.

Tabel 6. Hubungan siklus mentruasi dengan persentasi lemak tubuh

\begin{tabular}{|c|c|c|c|c|c|c|c|}
\hline \multirow{3}{*}{$\begin{array}{c}\text { Persentase } \\
\text { Lemak } \\
\text { Tubuh }\end{array}$} & \multicolumn{6}{|c|}{ Siklus Menstruasi } & \multirow{3}{*}{ p } \\
\hline & \multicolumn{2}{|c|}{ Teratur } & \multicolumn{2}{|c|}{$\begin{array}{l}\text { Tidak } \\
\text { Teratur }\end{array}$} & \multicolumn{2}{|c|}{ Total } & \\
\hline & f & $\%$ & $f$ & $\%$ & f & $\%$ & \\
\hline Overweight & 26 & 29,1 & 2 & 2,5 & 28 & 100 & \\
\hline Normal & 42 & 57 & 9 & 11,4 & 51 & 100 & 0,31 \\
\hline Total & 68 & 86,7 & 11 & 13,9 & 79 & 100 & \\
\hline
\end{tabular}

\section{PEMBAHASAN}

Berdasarkan Tabel 3, didapatkan sebagian besar populasi memiliki persentase lemak tubuh dalam kategori non overweight $64,6 \%$, sedangkan overweight $35,4 \%$. Banyak faktor yang mempengaruhi obesitas diantaranya genetik, nutrisi, psikologi, hormonal, neurologis dan social. ${ }^{15}$ Pola makan, faktor psikis dan kurangnya aktivitas fisik merupakan penyebab utama terjadi peningkatan obesitas di tengah masyarakat yang makmur. ${ }^{16}$

Pada Tabel 4, sebagian besar responden memiliki siklus menstruasi yang teratur yaitu dengan rentang 21-35 hari. Pada penelitian yang dilakukan oleh Gharravi tahun 2009 di Iran, terhadap 106 sampel dengan variasi IMT mulai dari $15 \mathrm{~kg} / \mathrm{m}^{2}$ hingga 29,9 $\mathrm{kg} / \mathrm{m}^{2}$ didapatkan $38 \%$ mahasiswi di Iran mengalami ketidak teraturan siklus menstruasi yaitu diantaranya $4,5 \%$ responden obesitas. ${ }^{17}$ Hal tersebut serupa dengan penelitian ini yaitu didapatkan responden dengan IMT non overweight lebih banyak yang mengalami ketidakteraturan siklus menstruasi dibandingkan responden overweight dan obesitas.

Obesitas pada wanita dapat menimbulkan risiko gangguan mentruasi dan penyakit lain seperti meningkatnya prevalensi kanker yang sensitif terhadap hormon wanita. Sel-sel lemak tidak hanya penyimpan energi tetapi juga berperan sebagai organ endokrin yang aktif sehingga menimbulkan kerentanan penyakit pada obesitas. ${ }^{18}$
Sebagian besar panjang siklus menstruasi pada wanita adalah 28 hari. Wanita dengan IMT yang lebih besar memang memiliki risiko untuk mengalami siklus menstruasi tidak teratur. ${ }^{19}$ Ketidakteraturan siklus menstruasi juga dipengaruhi oleh onset menstruasi diatas umur 14 tahun, tingkat depresi, paritas dan lain lain. ${ }^{13,19}$ Penelitian ini hanya meneliti pengaruh lemak terhadap siklus menstruasi tetapi tidak melihat tingkat depresi serta onset menstruasi.

Tabel 5 menunjukkan responden overweight lebih banyak yang mengalami siklus menstruasi teratur sebanyak 20 orang $(25,3 \%)$ dibandingkan dengan overweight terhadap ketidakteraturan mestruasi dengan jumlah 2 orang (2,5\%). Hasil uji statistik didapatkan $\mathrm{p}=0,77$, hal ini menunjukkan bahwa tidak terdapat hubungan bermakna antara IMT dengan keteraturan siklus menstruasi.

Berbeda dengan penelitian Rowland et al pada tahun 2002 menyebutkan bahwa lemak tubuh yang diukur melalui IMT, memiliki hubungan dengan keteraturan siklus menstruasi. Wanita dengan kategori IMT berat badan berlebih memiliki siklus menstruasi lebih panjang dibandingkan wanita dengan IMT kategori normal $(\mathrm{OR}=5,4, \mathrm{Cl}=2,1-13,7) .{ }^{19}$ Penyebab lebih panjangnya siklus menstruasi pada wanita obesitas adalah estrogen yang meningkat dalam darah akibat produksi dari lemak yang berlebih dalam tubuh. $^{22}$

Berdasarkan Tabel 6 didapatkan responden overweight yang mengalami ketidakteraturan menstruasi hanya kurang dari lima responden sedangkan jumlah responden non overweight yang mengalami ketidakteraturan menstruasi lebih banyak dibandingkan responden overweight. Hasil uji statistik, tidak ada hubungan persentase lemak tubuh dengan siklus menstruasi.

Hasil ini sejalan dengan penelitian Anindita tahun 2010 pada 43 siswi SMA Negeri 1 Salatiga menyatakan bahwa tidak ada hubungan persentase lemak tubuh dengan siklus menstruasi dengan $p=0,113 .{ }^{21}$ Terdapat 51,2\% responden overweight dan obesitas dan $14 \%$ responden tersebut mengalami ketidakteraturan siklus menstruasi.

Berbeda halnya dengan penelitian yang dilakukan Rakhmawati pada tahun 2012 didapatkan 
persentase lemak tubuh berpengaruh terhadap siklus menstruasi yaitu seorang obesitas memiliki kejadian 1,86 kali lebih besar untuk mengalami gangguan siklus menstruasi dibandingkan seorang dengan kategori persentase lemak normal. Dalam penelitian tersebut, sampel yang digunakan adalah 60 orang yaitu 30 orang normal dan 30 orang obesitas. ${ }^{22}$ Sedangkan dalam penelitian ini sampel yang mengalami overweight dan obesitas hanya berjumlah 28 orang dari 79 orang, sehingga kurang representatif dalam membandingkan responden normal dan yang obesitas. Perbedaan juga terlihat pada hasil penelitian Dahliansyah yang menyatakan ada hubungan antara persentase lemak tubuh dengan keteraturan siklus menstruasi $(p=0.013){ }^{7}$

\section{SIMPULAN}

Tidak terdapat hubungan antara IMT dengan keteraturan siklus menstruasi pada mahasiswi Fakultas Kedokteran Universitas Andalas.

Tidak terdapat hubungan antara persentase lemak tubuh dengan keteraturan siklus menstruasi pada mahasiswi Fakultas Kedokteran Universitas Andalas.

\section{DAFTAR PUSTAKA}

1. Diaz AMRL, Breech LL.Menstruation in girls and adolescents: using the menstrual cycle as a vital sign. Pediatrics. 2006;118(5):2245-50.

2. MacGregor, Chavez M, Elias SG. Postmenopausal breast cancer risk and cumulative number of menstrual cycles. Cancer Epidemiology Biomarkers and Prevention. 2005;14(4):799-804

3. Wei S, Schmidt MD, Dwyer T, Norman RJ, and Venn AJ. Obesity and menstrual irregularity: associations with SHBG, testosterone, and insulin. Obesity (Silver Spring). 2009;17(5):1070-6.

4. Rofiq A. Persentase lemak tubuh dan lingkar pinggang sebagai faktor risiko bagi ketidakteraturan siklus menstruasi pada remaja Putri (skripsi). Semarang: Universitas Diponegoro; 2009.

5. Price SA, Wilson LM. Patofisiologi konsep klinis proses-proses penyakit (terjemahan). Jakarta: EGC. 2006.
6. World Health Organization. Obesity. 2009. Tersedia dari: URL: HYPERLINK. http://www.who. int/topics/obesity/en/.

7. Dahliansyah. Hubungan indeks massa tubuh dan persentase lemak tubuh dengan usia menarche dan keteraturan siklus menstruasi (studi pada siswi SMPN I Hulu Gurung Kabupaten Kapuas Hulu Kalimantan Barat Tahun 2007) (skripsi). Semarang: Universitas Diponegoro; 2008.

8. Hanafi M. Pengaruh obesitas (hiperkolesterolemia) terhadap kejadian amenore. 2009.

9. Katherine MF, Margaret DC, Cynthia LO, Clifford LJ. Prevalence of obesity and trends in the distribution of body mass index among US adults, 1999-2000. JAMA. 2002;288(14):1723-7.

10. Pradjono J. Prevalensi penyakit tidak menular di Indonesia menurut pendekatan STEPS fakor risiko (data study morbiditas). Jakarta: Department Kesehatan; 2003.

11. Stein CJ, Colditz. The Epidemic of obesity. The Journal of Clinical Endocrinology and metabolism. 2004;89(6):2522-5.

12. Sudibjo P. Penilaian Persentase lemak badan pada populasi Indonesia dengan metode anthropometris. 2011.

13. Harlow SD, Matanoski GM. The association between weight, physical activity, and stress and variation in the length of the menstrual cycle. American Journal of Epidemiology. 1991; 133(1):38-49.

14. Jafar N. Sindrom metabolik. Makassar: Program Studi IImu Gizi Fakultas Kesehatan Masyarakat Universitas Hasannudin. 2011.

15. Rahmatullah, Pasiyandan JLL. Faal paru pada obesitas. Majalah Kedokteran Indonesia. 2000;50(5):224-30.

16. El Baz FM, Eman AA, Amal AA, Terez BK, Fahmy A. Impact of obesity and body fat distribution on pulmonary function. Egyptian Journal Of Bronchology. 2009;3(1):49-58.

17. Gharravi AM. Menstrual cycle patterns of college students in Gorgan-Northeast of Iran: identify its association with sociodemographic factors. Iran: Department of Anatomy School of Medicine Gorgan University of Medical Sciences. Erciyes Med J 2009;31(4):331-8. 
18. Munster K, Schmidt L, Helm P. Length and variation in the menstrual cycle-a cross-sectional study from a Danish county. British Journal of Obstetrics and Gynaecology. 1992;99(5):422-9.

19. Rowland AS, Baird DD, Long S. Influence of medical conditions and lifestyle factors on the menstrual cycle. Epidemiology. 2002:13(6):668-74.

20. Berek JS. Berek \& Novak's gynecology. Philadelphia USA : Lippincott Williams and Wilkin; 2007.
21. Anindita YG. Hubungan antara asupan serat dan persentase lemak tubuh dengan siklus menstruasi pada remaja putri (skripsi). Semarang: Program Studi IImu Gizi Fakultas Kedokteran Universitas Diponegoro; 2010.

22. Rakhmawati A. Hubungan Obesitas dengan kejadian gangguan siklus menstruasi pada wanita usia dewasa. Semarang: Fakultas Kedokteran Universitas Diponegoro; 2012. 